\title{
Low Serum Paraoxonase-1 Lactonase and Arylesterase Activities in Obese Children and Adolescents
}

\section{Low Serum Paraoxonase-1 Lactonase and Arylesterase Activities in Obese Children and Adolescents}

\author{
Raluca Sandor ${ }^{1}$, Daniel Leucuta ${ }^{2}$, Eleonora Dronca ${ }^{3 *}$, Alexandru Niculae $^{1}$, \\ Victoria $\mathrm{Cret}^{4}$, Ciprian Silaghi ${ }^{5}$, Soimita Suciu ${ }^{6}$
}

1. Faculty of Medicine, Iuliu Hatieganu University of Medicine and Pharmacy, Cluj-Napoca, Romania; 2. Department of Medical Informatics and Biostatistics, Iuliu Hatieganu University of Medicine and Pharmacy, Cluj-Napoca, Romania; 3. Department of Medical Genetics, Iuliu Hatieganu University of Medicine and Pharmacy, Cluj-Napoca, Romania; 4. Paediatric Emergency County Hospital, 1st Paediatric Clinic, Cluj-Napoca, Romania; 5. Department of Medical Biochemistry, Iuliu Hatieganu University of Medicine and Pharmacy, Cluj-Napoca, Romania; 6. Department of Physiology, Iuliu Hatieganu University of Medicine and Pharmacy, Cluj-Napoca, Romania

\begin{abstract}
Serum paraoxonase-1 (PON1) binds mainly to high density lipoproteins (HDLs) and protects low density lipoproteins (LDLs) against oxidation. While paraoxonase and arylesterase activities are traditionally assayed, lactonase activity, accounting for protection against LDL oxidation, was less investigated in obese children and adolescents. Therefore, we aimed to measure lactonase, paraoxonase and arylesterase activities, oxidized $L D L$ (ox-LDL) and malondialdehyde (MDA) levels in obese children and adolescents.

Study population included 68 children (35 obese and 33 normal-weight). Arylesterase and paraoxonase activities were assayed spectrophotometrically. Lactonase activity, ox-LDL and MDA levels were measured using a pH-sensitive colorimetric assay, an ELISA technique and a fluorimetric method, respectively. The lipid profile was assessed by common methods.

Lactonase and arylesterase activities were decreased in the presence of obesity. MDA, but not ox-LDL levels, showed significant differences between groups. Multiple regression analysis identified a reciprocal relationship and a possible association between lactonase and arylesterase activities and obesity.
\end{abstract}

Keywords: paraoxonase, lactonase, arylesterase, childhood obesity, low density lipoproteins, malondialdehyde

\section{Rezumat}

Paraoxonaza-1 serica (PON1) se leaga in principal de lipoproteinele cu densitate mare (HDL) si protejeaza lipoproteinele cu densitate joasa (LDLs) impotriva oxidarii. In timp ce activitatile paraoxonazica si arilesterazica

*Corresponding author: Eleonora Dronca, "Iuliu Hatieganu" University of Medicine and Pharmacy Cluj-Napoca, Romania, e-mail: eleonora.dronca@umfcluj.ro 
sunt analizate in mod traditional, activitatea lactonazica, cea care confera de fapt protectia impotriva oxidarii $L D L$, a fost mai putin investigata la copiii si adolescentii obezi. Prin urmare, in acest studiu, ne-am propus sa cuantificam activitatile lactonazica, paraoxonazica si arilesterazica, nivelurile de LDL oxidat (ox-LDL) si malondialdehida (MDA) la copiii si adolescentii cu obezitate.

Lotul de studiu a inclus 68 de copii (35 cu obezitate si $33 \mathrm{cu}$ greutate normala). Activitatile paraoxonazica si arilesterazica au fost analizate spectrofotometric. Activitatea lactonazica, nivelurile de ox-LDL si MDA au fost masurate cu ajutorul unui test colorimetric sensibil la pH, o tehnică ELISA si respectiv, o metoda fluorimetrica. Profilul lipidic a fost evaluat prin metode obisnuite.

Activitatile lactonazica si arilesterazica au prezentat valori scazute in prezența obezitatii. Nivelul MDA, dar nu si cel de ox-LDL, a aratat diferente semnificative intre grupurile analizate. Analiza de regresie multipla a identificat o relatie de reciprocitate si o posibila asociere intre activitatile lactonazica si arilesterazica, si obezitatea la copii si adolescenti

Cuvinte cheie: paraoxonaza, lactonaza, arilesteraza, obezitate infantila, lipoproteine cu densitate joasa, malondialdehida

Received: $14^{\text {th }}$ July 2015; Accepted: 22 $2^{\text {nd }}$ September 2015; Published: $28^{\text {th }}$ October 2015

\section{Introduction}

Paraoxonase-1 (PON1), a member of the paraoxonase family, is synthesized in the liver and transported in the plasma mainly by the high density lipoprotein (HDL) particles from where it can be transferred in the areas of low density lipoprotein (LDL) accumulation, where it prevents its oxidation (1). From a functional perspective, PON1 hydrolyzes a broad spectrum of molecules ranging from organophosphates (OPs) to lactones (2), as it performs multiple tasks depending on its substrate and networking capacity of its active center residues (3). While paraoxonase (Po.ase) and arylesterase (Ar.ase) activities are being traditionally assayed, lactonase (Lct. ase) activity, which accounts for HDL-mediated protection against LDL oxidation (4), has been less investigated. These activities are modulated by single nucleotide polymorphisms in the promoter (mainly c. $-108 \mathrm{C}>\mathrm{T}$ or $r$ 705379) and the coding region (p.Leu55Met or $r s 854560$ and p.Gln192Arg or $r s 662$ ) of the PON1 gene. While the c. $-108 \mathrm{C}>\mathrm{T}$ and the p.Leu55Met polymorphisms influence enzyme concentration and stability (5), the Gln-to-Arg substitution at position 192 accounts for great variations of the Po.ase activity (6), from the $G \ln (Q)$ isoform with the lowest activity to the Arg (R) isoform with the highest activity (7). Furthermore, oxidative stress influences the three activities differently, Lct.ase being the most susceptible (8).

Childhood obesity, defined as a body mass index (BMI) higher than the $95^{\text {th }}$ percentile for the same age and sex, is a major public health issue affecting millions of children worldwide. Excessive adiposity increases the risk for atherosclerosis-related coronary artery disease by promoting inflammation, oxidative stress and high plasma cholesterol levels, which negatively influence $P O N 1$ gene transcription (9) and activity (8). In adults, low PON1 levels are associated with conditions that involve lipid peroxidation and systemic inflammation such as diabetes mellitus or metabolic syndrome and are an independent risk factor for coronary heart disease (10). Furthermore, low levels of Ar.ase or Po.ase have been observed in obese children (11-14), but Lct. ase, considered the physiologic activity of PON1 (2), has scarcely been investigated in this condition (14). Having these in mind, we undertook a complex approach to compare Lct.ase, Po.ase and Ar.ase, along with oxidized LDL (ox-LDL), malondialdehyde (MDA) and lipid profile in a group of children and adolescents with non-genetic obesity $v s$. normal-weight children. 


\section{Subjects and Methods}

\section{Study population}

The study population consisted of 68 children, 35 obese (OB) and 33 normal-weight (Control, C), consecutively recruited from the local Pediatric Hospitals. All participants underwent a complete standard physical examination. BMI was calculated as the ratio of the weight (expressed in kilograms, $\mathrm{kg}$ ) to the square of height (expressed in meters, $\mathrm{m}^{2}$ ). The children were classified as obese or normal-weight according to the WHO-BMI percentiles with the cut-off limit for the study group set at the $95^{\text {th }}$ percentile. The children had no previous dietary interventions, nor were enrolled in any physical education programmes. Children suffering from any chronic diseases (e.g. diabetes mellitus) or presenting any acute inflammatory conditions were excluded from study. An informed written consent was obtained from all the parents or legal tutors of children included in the study. The research protocol was developed in accordance with the WMA Declaration of Helsinki and was approved by the University Ethics Committee.

\section{Blood sample collection}

Venous blood samples were drawn in clot-activator vacutainers in the morning, following a 12-hour overnight fast. The serum, isolated by low-speed centrifugation, was used for lipid profile determination and the remaining quantity was immediately divided into aliquotes and stored at $-80^{\circ} \mathrm{C}$ for later assay of PON1 activities, MDA and ox-LDL levels.

\section{PON1 enzymatic activities}

PON1 Ar.ase, salt-inhibited arylesterase (siAr.ase) and salt-stimulated paraoxonase (ssPo. ase) activities were determined using phenyl acetate and paraoxon as substrates, according to Eckerson et al. (7), with slight modifications.

Briefly, siAr.ase and Ar.ase were measured using an incubation mixture containing phenyl acetate (Sigma, USA) in $1 \mathrm{mM} \mathrm{CaCl}, 20 \mathrm{mM}$ Tris-HCl buffer $(\mathrm{pH} 8)$ with and without $1 \mathrm{M}$ $\mathrm{NaCl}$, to which serum was added in order to initiate the reaction. The rate of substrate hydrolysis was established measuring the increase in absorbance at $270 \mathrm{~nm}$. The enzymatic activity (expressed in $\mathrm{kU} / \mathrm{L}$ ) was calculated using the corresponding molar extinction coefficient for phenol $\left(1,310 \mathrm{M}^{-1} \mathrm{~cm}^{-1}\right)$.

The ssPo.ase working mixture contained $1 \mathrm{mM}$ paraoxon (diethyl 4-nitrophenyl phosphate, Sigma-Aldrich Chemie GmbH, Germany), $1 \mathrm{mM}$ $\mathrm{CaCl}_{2}$ and $2 \mathrm{M} \mathrm{NaCl}$ in $50 \mathrm{mM}$ glycine- $\mathrm{NaOH}$ buffer ( $\mathrm{pH}$ 10.5). After adding the serum, the hydrolysis of paraoxon was recorded at 412 $\mathrm{nm}$. The molar extinction coefficient of 18,290 $\mathrm{M}^{-1} \mathrm{~cm}^{-1}$ for $\mathrm{p}$-nitrophenol was used to calculate the enzymatic activity, expressed in U/L.

Lct.ase activity (expressed in $\mathrm{kU} / \mathrm{L}$ ) was measured by adapting the $\mathrm{pH}$-sensitive colorimetric assay proposed by Khersonsky and Tawfik (2). The reaction mixture contained $1 \mathrm{mM}$ $\delta$-valerolactone (Acros Organics, Belgium) in $0.1 \mathrm{mM} \mathrm{m}$-cresol purple (from $60 \mathrm{mM}$ stock solution in dimethyl sulfoxide), $1 \mathrm{mM} \mathrm{CaCl}$ and $150 \mathrm{mM} \mathrm{NaCl}$ in $2.5 \mathrm{mM}$ bicine buffer $\left(\mathrm{pH}^{2} 8.3\right)$. After adding serum to the assay mixture, the hydrogen ions release by the 5-hydroxyvaleric acid (the product of Lct.ase action) was recorded spectrophotometrically at $577 \mathrm{~nm}$. The initial rate of hydrolysis was calculated using the slope value (in units of absorbance change per minute) multiplied by a rate factor derived from a standard calibration curve obtained with acetic acid. Units were defined as the number of micromoles of acid produced per time unit.

All PON1 activities were determined at $25^{\circ} \mathrm{C}$ with a V-530 Spectrophotometer using a Peltier thermostated cell holder, equipped with a magnetic stirrer (Jasco, USA). A blank sample containing incubation mixture without serum was used in order to correct for the spontaneous hydrolysis of the substrate. 


\section{PON1 phenotype distribution}

The ratio of ssPo.ase to siAr.ase activities (double-substrate method applied on the logarithm-transformed data) was used to identify individual phenotypes according to Eckerson et al. (7) with slight modifications. Knowing that $\mathrm{NaCl}$ differently influences Po.ase and Ar.ase activities, which correspond to a specific phenotype, we have used the ssPo.ase activity and the $s i$ Ar.ase activity to obtain a better phenotype differentiation. The ratios were trimodally distributed on the histogram, corresponding to low activity - AA phenotype (isoform QQ), intermediate activity - $\mathrm{AB}$ phenotype (isoform $\mathrm{QR}$ ) and high activity - BB phenotype (isoform RR).

\section{Oxidized LDL (ox-LDL) levels}

Serum ox-LDL levels were measured using an Oxidized LDL Competitive ELISA assay kit (Mercodia AB, Sweden) according to the manufacturer's instructions, on a Sunrise Tecan microplate reader (Tecan Group, Switzerland).

\section{Malondialdehyde (MDA) levels}

MDA levels were assayed using the fluorometric method proposed by Conti et al. (15), on a Perkin-Elmer UK model LS 45 Fluorescence Spectrometer (Perkin Elmer, UK). MDA was treated with 1,3-diethyl-2-thiobarbituric acid in an acid medium and the resulted fluorescent compound was extracted with butanol and determined by synchronous fluorescence spectroscopy with $\Delta \lambda=14 \mathrm{~nm}$ between the excitation (515 $\mathrm{nm})$ and emission wavelengths.

\section{Other parameters}

Serum triacylglycerols (TG), HDL and total cholesterol (TC) were assayed on an Architect C4000 analyzer (Abbott, USA) using commercially available kits. LDL levels were calculated using the Friedewald formula (LDL=TC-HDLTG/5), all subjects having TG levels below 3.9 $\mathrm{mm} / \mathrm{l}$. The atherogenic index of plasma (AIP) was expressed as logarithm of the molar ratio of TG to HDL (16).

\section{Statistical analysis}

Qualitative data was presented as counts and percentages. The association between qualitative variables was assessed using the Chi-square test or the Fisher exact test. The normal distribution of data was checked with strip-chart, quantile-quantile plot and Shapiro-Wilk test.

Quantitative data was presented as mean and standard deviation (for normally distributed data) or by median and interquartile range (for non-normally distributed data). To check for differences between two independent groups of quantitative data, the Mann-Whitney U test (for non-normally distributed data) or the Student test (for normally distributed data) were used. The Lct.ase and Ar.ase activities were assessed against several explanatory variables: obesity (coded 1-yes, 0-no), age, gender, HDL, LDL, ox-LDL, TG and MDA. The relationship between obesity and other explanatory variables was assessed with logistic regression.

For all regression analysis we performed the univariate analysis. We built the full models and then using a stepwise backward/forward model selection based on the Akaike information criterion we selected the variables for the final models. Results were presented as coefficients/odds ratios and $95 \%$ CI. For all statistical tests the significance level alpha was set at 0.05 and the two-tailed $p$ value was computed. The statistical analysis was performed in R environment for statistical computing and graphics, version 3.0.1 (17).

\section{Results}

Baseline clinical and laboratory parameters of the study groups are presented in Table I.

Statistical analysis did not show significant differences regarding age, gender distribution, TG and ox-LDL. 
Table I. Baseline clinical and laboratory parameters of the study groups

\begin{tabular}{lccc}
\hline Variable & Control $(\mathrm{n}=33)$ & Obese $(\mathrm{n}=35)$ & $\mathrm{p}$ \\
\hline Age $(\mathrm{years})$ & $11.85 \pm 2.83$ & $12.19 \pm 3.41$ & 0.658 \\
\hline Female n $(\%)$ & $24(66.67)$ & $20(60.61)$ & 0.601 \\
\hline TC $(\mathrm{mmol} / \mathrm{L})$ & $3.43[3.12-3.92]$ & $4.12[3.47-4.62]$ & $<0.001$ \\
\hline LDL $(\mathrm{mmol} / \mathrm{L})$ & $1.48[1.15-2.12]$ & $2.4[1.92-2.99]$ & $<0.001$ \\
\hline HDL $(\mathrm{mmol} / \mathrm{L})$ & $1.5 \pm 0.16$ & $1.16 \pm 0.22$ & $<0.001$ \\
\hline TG $(\mathrm{mmol} / \mathrm{L})$ & $0.79[0.57-1.13]$ & $0.9[0.69-1.13]$ & 0.144 \\
\hline Ox-LDL $(\mathrm{U} / \mathrm{L})$ & $47.02 \pm 14.67$ & $46.08 \pm 10.49$ & 0.763 \\
\hline Ox-LDL/HDL & $0.8 \pm 0.25$ & $1.01 \pm 0.24$ & $<0.001$ \\
\hline MDA $(\mu \mathrm{mol} / \mathrm{L})$ & $1.65[1.58-2.11]$ & $2.62[2-2.97]$ & $<0.001$ \\
\hline PON1 activities & & & \\
\hline Ar.ase $(\mathrm{kU} / \mathrm{L})$ & $66.55[61-85.1]$ & $54.87[48.42-61.09]$ & $<0.001$ \\
\hline ssPo.ase $(\mathrm{U} / \mathrm{L})$ & $214.1[154.3-470.9]$ & $288[172.28-477.55]$ & 0.414 \\
\hline Lct.ase $(\mathrm{kU} / \mathrm{l})$ & $14.2[9.39-28.07]$ & $10.4[8.87-12.11]$ & 0.013 \\
\hline PON1 activities/HDL & & $5.71[4.01-10.2]$ & 0.02 \\
\hline ssPo.ase/HDL & $3.45[2.62-7.38]$ & $1.15[1.02-1.47]$ & 0.82 \\
\hline Ar.ase/HDL & $1.13[1-1.5]$ & $0.23[0.21-0.26]$ & 0.33 \\
\hline Lct.ase/HDL & $0.26[0.15-0.51]$ & -16 & \\
\hline
\end{tabular}

n (\%) - number (percentage); TC - total cholesterol; LDL - low density lipoproteins; HDL - high desity lipoproteins; TG - triacylglycerols; OxLDL - oxidized LDL; MDA - malondialdehyde; Ar.ase - arylesterase; ssPo.ase - salt-stimulated paraoxonase; Lct.ase - lactonase. Non-normally distributed data are presented as median [lower quartile - upper quartile]; Normally distributed data are presented as mean \pm standard deviation (SD)

Serum TC, LDL and MDA levels were significantly higher and HDL levels were significantly lower in obese children, while AIP values were in normal limits for both groups (OB: -0.09 \pm 0.21 vs. C: $-0.27 \pm 0.20 ; \mathrm{p}<0.001)$.

There were no statistically significant differences between obese and control groups regard- ing the PON1 phenotype distribution $[\mathrm{AA}=19$ (54.28\%); $\mathrm{AB}=11 \quad(31.42 \%) ; \mathrm{BB}=5 \quad(14.28 \%)$ vs. $\mathrm{AA}=17(51.51 \%) ; \mathrm{AB}=11(33.33 \%) ; \mathrm{BB}=5$ $(15.15 \%) ; p=0.98]$.

Ar.ase and Lct.ase activities were significantly decreased in obese children compared to controls (Figure 1), but ssPo.ase levels were not
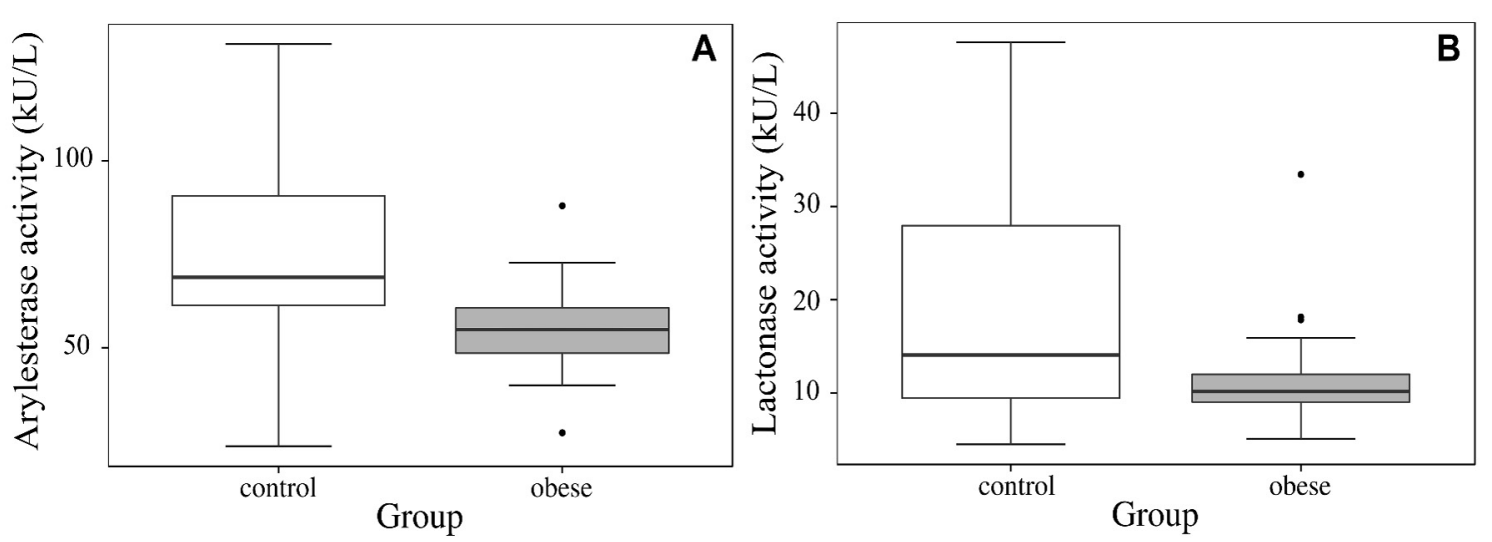

Figure 1. Lct.ase (A) and Ar.ase (B) activities in the investigated groups 
significantly different. After dividing each PON1 activity by the HDL level, there were no longer statistically significant differences between subjects and controls for Ar.ase and Lct.ase activities (Table I).

In the univariate linear regression, obesity was associated with decreased Lct.ase and Ar.ase $\left(\mathrm{B}=-8.53, \mathrm{R}^{2}=0.18 ; \mathrm{p}<0.001 ; \mathrm{B}=-19.29\right.$, $\mathrm{R}^{2}=0.19 ; \quad \mathrm{p}<0.001$, respectively). Decreased
HDL was positively associated with Lct.ase and Ar.ase activities $\left(\mathrm{B}=0.3 ; \mathrm{R}^{2}=0.08 ; \mathrm{p}<0.05\right.$; $\mathrm{B}=0.72 ; \mathrm{R}^{2}=0.095 ; \mathrm{p}=0.01$, respectively).

Multiple regression analysis showed that obesity was associated with decreased Ar.ase and Lct.ase activities even when the parameters were adjusted for the HDL levels (Tables II, III and $I V)$. The stepwise selection procedures used to build all the final regression models removed

Table II. Multiple linear regression analysis for Ar.ase and Let.ase as dependent variables

\begin{tabular}{lccc}
\hline Ar.ase* & $\mathbf{B}$ & $\mathbf{( 9 5 \%} \mathbf{C I})$ & $\mathbf{p}$ \\
\hline Obese (yes/no) & -19.43 & {$[(-28.1)-(-10.76)]$} & $<0.001$ \\
ssPo.ase activity (U/L) & 0.0387 & $0.02-0.06$ & $<0.001$ \\
\hline Lct.ase** & $\mathbf{B}$ & $\mathbf{( 9 5 \% ~ C I )}$ & $\mathbf{p}$ \\
\hline Obese (yes/no) & -11.14 & {$[(-16.22)-(-6.05)]$} & $<0.001$ \\
Age (years) & -0.6 & {$[(-1.27)-0.07]$} & 0.077 \\
LDL (mmol/L) & 3.83 & $0.34-7.32$ & 0.032 \\
\hline
\end{tabular}

Ar.ase - arylesterase; ss Po.ase - salt-stimulated paraoxonase; Lct.ase - lactonase; LDL - low density lipoproteins; B - unstandardized regression coefficient; $95 \%$ CI $-95 \%$ confidence interval. The adjusted determination coefficients were $0.35^{*}$ and $0.31 * *$ respectively $(\mathrm{p}<0.001)$

Table III. Multiple linear regression analysis adjusted for HDL using Ar.ase, Po.ase and Lct.ase as dependent variables

\begin{tabular}{lccccc}
\hline Activity & Variable & B & $\mathbf{( 9 5 \% ~ C I )}$ & p & P model \\
\hline \multirow{2}{*}{ Ar.ase $^{\dagger}$} & Obese & -17.28 & {$[(-30.58)-3.99]$} & 0.012 & $<0.001$ \\
& HDL & 5.9 & {$[(-20.29)-32.09]$} & 0.654 & \\
\multirow{2}{*}{ ssPo.ase $^{\dagger \dagger}$} & Obese & 66.3 & {$[(-97.48)-230.07]$} & 0.422 & 0.523 \\
\multirow{2}{*}{ Lct.ase $^{\dagger+\dagger}$} & HDL & 184.58 & {$[(-137.98)-507.13]$} & 0.257 & \\
& Obese & -8.03 & {$[(-14.17)-1.9]$} & 0.011 & 0.002 \\
\hline
\end{tabular}

Ar.ase - arylesterase; ssPo.ase - salt-stimulated paraoxonase; Lct.ase - lactonase; HDL - high density lipoproteins; B - unstandardized regression coefficient; $95 \% \mathrm{CI}-95 \%$ confidence interval. The adjusted determination coefficients were $0.16^{\dagger}, 0.01^{\dagger \dagger}$, $0.15^{\dagger \dagger}$ respectively

Table IV. Multiple logistic regression analysis for obesity as a dependent variable

\begin{tabular}{lccc}
\hline Variable & OR adjusted & $(95 \% \mathrm{CI})$ & $\mathrm{p}$ \\
\hline HDL $(\mathrm{mmol} / \mathrm{L})$ & 0.72 & $(0.53-0.86)$ & 0.005 \\
LDL (mmol/L) & 1.09 & $(1.03-1.2)$ & 0.018 \\
ssPo.ase (U/L) & 1.01 & $(1-1.02)$ & 0.02 \\
Ar.ase (kU/L) & 0.92 & $(0.85-0.98)$ & 0.02 \\
Lct.ase (kU/L) & 0.73 & $(0.5-0.89)$ & 0.026 \\
Ox-LDL (U/L) & 1.07 & $(0.97-1.23)$ & 0.224 \\
\hline
\end{tabular}

HDL - high density lipoproteins, LDL - low density lipoproteins, ssPo.ase - salt-stimulated paraoxonase, Ar.ase - arylesterase, Lct.ase - lactonase, ox-LDL - oxidized low density lipoproteins; OR - odds ratio; 95\% CI - 95\% confidence interval 
MDA as a possible explanatory variable candidate.

\section{Discussion}

The main finding of our research was that PON1 Lct.ase and Ar.ase activities, but not ssPo. ase, are decreased in the presence of excessive adiposity. Until now, relatively little effort has been made to investigate the role of PON1 in obesity, and the few published results are inconsistent. In obese adults, both low (18-21) or unchanged levels of Po.ase and Ar.ase (22) have been reported. Similarly, in obese children and adolescents, either low $(11,23,24)$, unaffected levels of Po.ase and Ar.ase (25-27) or incresed levels of Ar.ase (28) have also been observed. Recently, unchanged (25) or reduced (14) levels of Lct.ase activity (assayed with dihydrocoumarin and 5-thiobutyl butyrolactone, respectively) have been reported in obese children.

The discrepancies between the data regarding PON1 activities in obese vs. control subjects could be explained by the relatively small size of the investigated groups, the great variability of PON1 activities in the same ethnic population, the complex nature of obesity (which depends on both genetic and environmental factors), and lifestyle, which could influence HDL composition and thus PON1 stability and activities. Furthermore, the differences between the methods used for assaying PON1 activities (e.g. the composition of assaying mixture) could be another cause of discrepancy. The $\mathrm{pH}$-indicator assay which we used to monitor $\delta$-valerolactone hydrolysis permits the measurement of the initial rate but not of the entire reaction course (29). Moreover, while $\delta$-valerolactone and phenyl acetate bind in a similar fashion to the PON1 active site and use the same catalytic mechanism, the hydrolysis of paraoxon (an aromatic phosphotriester) and of dihydrocoumarin (an aromatic lactone) uses distinctive parts of the active site network, therefore the binding and catalytic mechanisms are dissimilar (3). All the above could explain the Ar.ase and Lct.ase behavior observed in our study, and the unchanged Po.ase and Lct.ase reported by Ruperez et al. (25) in the obese group.

The association of PON1 with HDL is a prerequisite for maintaining a normal serum enzyme activity. HDL lipidic and proteic components interact in order to promote PON1 secretion as well as maintaining its stability in the blood stream (30). As in our study, reduced HDL levels have been previously reported in obese children $(11,13,14,23,25)$. These alterations have been attributed to both an enhancement in the uptake of HDL by the adipocytes and an increase in the apoA-I catabolism in HDL particles. In the absence of ApoA-I, the PON1-HDL complex is less stable and PON1 loses its activity (mainly Lct.ase) faster than in normal controls (1, 10, $31,32)$. Therefore, due to a reduced level of the carrier and the instability of the PON1-HDL complex, low PON1 levels are to be expected. Accordingly, we observed that the differences between groups regarding the Ar.ase and Lct. ase activities lost their statistical significance after being divided by the HDL levels, suggesting that, in the case of the obese children, low HDL levels account, at least partially, for the diminished Ar.ase and Lct.ase.

Another factor which could affect PON1 levels is oxidative stress, observable not only in obese adults but also in obese children. In this respect, we have observed higher MDA levels (one of the end products of lipid peroxidation) in obese subjects. This increment has also been reported by Codoner-Franch et al. $(21,33)$.

PON1 is involved in the protection of LDL and HDL against oxidative alteration (34). Moreover, the enzyme is time-dependent inactivated by this process, due to an interaction of oxidized phospholipids and cholesterol esters with the free SH-group of cysteine-284 (the inhibition 
percent of LDL oxidation being higher than the percent lost in PON1 activity) (35).

These interactions influence the three activities differently, Lct.ase being the most susceptible (8). Current research indicates that the Ar.ase and mainly the Lct.ase activities are related to the protective capacity of PON1 against LDL oxidation, ox-LDL inducing the enzyme's "suicide-like" behavior by impairing the networking of its active site residues (8). Moreover, ox-LDL can induce HDL composition alteration (10) and decrease the PON1 gene expression (9). As obesity promotes oxidative stress, we expected to find high levels of serum ox-LDL in the obese subjects. Conversely, we did not observe statistically significant differences between the obese and the control groups, similar to Demirel et al. (36), Kelishadi et al. (37) and Ruperez et al. (25). Kelly et al. (38) found increased oxLDL levels in children with excessive adiposity, significantly associated with obesity only in the older subjects (12-18 years of age). However, statistically significant differences were observed between groups regarding the ox-LDL to HDL ratio, a parameter which better evaluates the risk for further developing atherosclerosis-related complications and thus the extent of the LDL alterations induced by oxidation/oxidative stress (39).

The unchanged ox-LDL levels in obese children could be due to a good antioxidant protection and/or an efficient and specific removal from their plasma by the macrophages and macrophage-like cells in the liver (40). In this respect, the AIP values observed in obese children indicated a low risk of atherosclerosis-related complications (16), as ox-LDL certainly plays an important role in atherogenesis.

The small sample size was definitely a limitation of this study, however our results underline the importance of further analyzing the relationship between PON1 and childhood obesity from the perspective of the Lct.ase activity. In order to enrich the results of the present study, large prospective studies are needed and other markers of oxidative stress should be analyzed.

\section{Conclusion}

Low PON1 Lct.ase and Ar.ase activities are associated with the presence of obesity in children and adolescents. This may account for a higher susceptibility to atherosclerosis-related diseases with age.

\section{Ackowledgements}

The authors would like to express their gratitude to all the children and their parents for accepting to participate in this study and would like to thank Professor Maria Dronca from the Biochemistry Department of the Iuliu Hatieganu University of Medicine and Pharmacy for supervising the research.

\section{Conflicts of interest}

The authors declare no potential conflicts of interest with respect to the research, authorship, and/or publication of this article.

\section{Funding}

This study was funded by Iuliu Hatieganu University of Medicine and Pharmacy, grant no. 22714/8/06.10.2011. Dr. Dronca E is a fellow of POSDRU grant no. 159/1.5/S/138776 with title: "Model colaborativ institutional pentru translatarea cercetarii stiintifice biomedicale in practica clinica - TRANSCENT".
Abbreviations
95\% CI - 95\% confidence interval AIP - atherogenic index of plasma apoA-I - apolipoprotein A-I Ar.ase - arylesterase activity 
BMI - body mass index

HDL - high density lipoprotein

Lct.ase - lactonase activity

LDL - low density lipoprotein

MDA - malondialdehyde

n (\%) - number (percentage)

OPs - organophosphates

OR - odds ratio

ox-LDL - oxidized LDL

Po.ase - paraoxonase activity

PON1 - Paraoxonase-1

SD - standard deviation

siAr.ase - salt-inhibited arylesterase activity

ssPo.ase - salt-stimulated paraoxonase activity

TC - total cholesterol

TG - serum triacylglycerols

\section{References}

1. Sorenson RC, Bisgaier CL, Aviram M, Hsu C, Billecke S, La Du BN. Human serum paraoxonase/arylesterase's retained hydrophobic N-terminal leader sequence associates with HDLs by binding phospholipids: Apolipoprotein A-I stabilizes activity. Arterioscler Thromb Vasc Bio. 1999;19:2214-25. DOI: 10.1161/01. ATV.19.9.2214

2. Khersonsky O, Tawfik D. Structure-reactivity studies of serum paraoxonase PON1 suggest that its native activity is lactonase. Biochemistry. 2005;44(16):6371-82. DOI: 10.1021/bi047440d

3. Ben-David M, Elias M, Filippi JJ, Du-ach E, Silman I, Sussman JL, et al. Catalytic versatility and backups in enzyme active sites: the case of serum paraoxonase 1 . J Mol Biol. 2012 May;418(3-4):181-96. DOI: 10.1016/j. jmb.2012.02.042

4. Aviram M, Kaplan M, Rosenblat M, Fuhrman B. Dietary antioxidants and paraoxonases against LDL oxidation and atherosclerosis development. Handb Exp Pharma. 2005;170:263-300. DOI: 10.1007/3-54027661-0_9

5. Deakin SP, James RW. Genetic and environmental factors modulating serum concentrations and activities of the antioxidant enzyme paraoxonase-1. Clin Sci (Lond). 2004 Nov;107(5):435-47. DOI: 10.1042/CS20040187

6. Browne RW, Koury ST, Marion S, Wilding G, Muti P, Trevisan M. Accuracy and biological variation of hu- man serum Paraoxonase-1 activity and polymorphism (Q192R) by kinetic enzyme assay. Clin Chem. 2007 Feb;53(2):310-7. DOI: 10.1373/clinchem.2006.074559

7. Eckerson HW, Wyte CM, La Du BN. The human serum paraoxonase/arylesterase polymorphism. Am J Hum Genet. 1983 Nov;35(6):1126-38.

8. Nguyen SD, Nguyen DH, Park CH, Kim MR, Sok DE. Oxidative inactivation of lactonase activity of purified human Paraoxonase-1(PON1). Biochim Biophys Acta. 2009 Mar;1790(3):155-60. DOI: 10.1016/j. bbagen.2008.11.009

9. Fuhrman B. Regulation of hepatic paraoxonase-1 expression. J Lipids. 2012; 2012:684010. DOI: 10.1155/2012/684010

10. She ZG, Chen HZ, Yan Y, Li H, Liu DP. The human paraoxonase gene cluster as a target in the treatment of atherosclerosis. Antioxid Redox Signal. 2012 Mar;16(6):597-632. DOI: 10.1089/ars.2010.3774

11. Koncsos P, Seres I, Harangi M, Illyés I, Józsa L, Gönczi F, et al. Human paraoxonase-1 activity in childhood obesity and its relation to leptin and adiponectin levels. Pediatr Res. 2010 Mar;67(3):309-13. DOI: 10.1203/ PDR.0b013e3181c9fb66

12. Seres I, Bajnok L, Harangi M, Sztanek F, Koncsos P, Paragh G. Alteration of PON1 activity in adult and childhood obesity and its relation to adipokine levels. Adv Exp Med Biol. 2010;660:129-42. DOI: 10.1007/978-1-60761-350-3_12

13. Torun E, Gökçe S, Ozgen İT, Aydın S, Cesur Y. Serum paraoxonase activity and oxidative stress and their relationship with obesity-related metabolic syndrome and non-alcoholic fatty liver disease in obese children and adolescents. J Pediatr Endocrinol Metab. 2014 Jul;27(7-8):667-75. DOI: 10.1515/jpem-2013-0337

14. Ferré N, Feliu A, García-Heredia A, Marsillach J, París $\mathrm{N}$, Zaragoza-Jordana M, et al. Impaired paraoxonase-1 status in obese children. Relationships with insulin resistance and metabolic syndrome. Clin Biochem. 2013 Dec;46(18):1830-6. DOI: 10.1016/j.clinbiochem.2013.08.020

15. Conti M, Moran PC, Levillain P, Lemonnier A. Improved fluorimetric determination of malondialdehyde. Clin Chem. 1991 Jul;37(7):1273-5.

16. Dobiásová M. AIP-atherogenic index of plasma as a significant predictor of cardiovascular risk: from research to practice. Vnitr Lek. 2006 Jan;52(1):64-71.

17. R Development Core Team. R: A Language and Envi- 
ronment for Statistical Computing. Vienna, Austria: the R Foundation for Statistical Computing. 2011; ISBN: 3-900051-07-0. Available online at http://www.R-project.org/.

18. Aslan M, Horoz M, Sabuncu T, Celik H, Selek S. Serum paraoxonase enzyme activity and oxidative stress in obese subjects. Pol Arch Med Wewn. 2011 Jun;121(6):181-6.

19. Ferretti G, Bacchetti T, Moroni C, Savino S, Liuzzi A, Balzola F, et al. Paraoxonase activity in high-density lipoproteins: a comparison between healthy and obese females. J Clin Endocrinol Metab. 2005 Mar;90(3):172833. DOI: $10.1210 /$ jc. $2004-0486$

20. Liang KW, Lee WJ, Lee IT, Lee WL, Lin SY, Hsu SL, et al. Persistent elevation of paraoxonase-1 specific enzyme activity after weight reduction in obese non-diabetic men with metabolic syndrome. Clin Chim Acta. 2011 Sep 18;412(19-20):1835-41. DOI: 10.1016/j. cca.2011.06.018

21. Samy W, Hassanian MA. Paraoxonase-1 activity, malondialdehyde and glutathione peroxidase in non-alcoholic fatty liver disease and the effect of atorvastatin. Arab J Gastroenterol. 2011 Jun;12(2):80-5. DOI: 10.1016/j.ajg.2011.04.008

22. Tabur S, Torun AN, Sabuncu T, Turan MN, Celik H, Ocak AR, et al. Non-diabetic metabolic syndrome and obesity do not affect serum paraoxonase and arylesterase activities but do affect oxidative stress and inflammation. Eur J Endocrinol. 2010 Mar;162(3):535-41. DOI: 10.1530/EJE-09-0732

23. Krzystek-Korpacka M, Patryn E, Hotowy K, Czapińska E, Majda J, Kustrzeba-Wójcicka I, et al. Paraoxonase (PON)-1 activity in overweight and obese children and adolescents: association with obesity-related inflammation and oxidative stress. Adv Clin Exp Med. 2013 Mar-Apr;22(2):229-36.

24. Zaki ME, El-Bassyouni H, Kamal S, El-Gammal M, Youness E. Association of serum paraoxonase enzyme activity and oxidative stress markers with dyslipidemia in obese adolescents. Indian J Endocrinol and Metab. 2014 May-Jun;18(3):340-4. DOI: 10.4103/22308210.131173

25. Rupérez AI, López-Guarnido O, Gil F, Olza J, Gil-Campos M, Leis R, et al. Paraoxonase-1 activities and genetic variation in childhood obesity. $\mathrm{Br}$ J Nutr. 2013 Nov;110(9):1639-47. DOI: 10.1017/ S0007114513001967
26. Agirbasli M, Tanrikulu A, Erkus E, Azizy M, Sevim BA, Kaya Z, et al. Serum paraoxonase-1 activity in children: the effects of obesity and insulin resistance. Acta Cardiol. 2014 Dec;69(6):679-85.

27. Desai S, Baker SS, Liu W, Moya DA, Browne RW, Mastrandrea $\mathrm{L}$, et al. Paraoxonase 1 and oxidative stress in paediatric non-alcoholic steatohepatitis. Liver Int. 2014 Jan;34(1):110-7. DOI: 10.1111/liv.12308

28. Huen K, Harley K, Beckman K, Eskenazi B, Holland N. Associations of PON1 and Genetic Ancestry with Obesity in Early Childhood. PLoS ONE. 2013 May;8(5):e62565. DOI: 10.1371/journal.pone.0062565

29. Chapman E, Wong CH. A pH sensitive colorimetric assay for the high-throughput screening of enzyme inhibitors and substrates: a case study using kinases. Bioorg Med Chem. 2002 Mar;10(3):551-5. DOI: 10.1016/ S0968-0896(01)00306-6

30. James RW, Deakin SP. The importance of high-density lipoproteins for paraoxonase-1 secretion, stability, and activity. Free Radic Biol Med. 2004 Dec;37(12):198694. DOI: 10.1016/j.freeradbiomed.2004.08.012

31. Gaidukov L, Tawfik DS. High affinity, stability and lactonase activity of serum paraoxonase PON1 anchored on HDL with ApoA-I. Biochemistry. 2005 Sep;44(35):11843-54. DOI: 10.1021/bi050862i

32. Noto H, Hashimoto Y, Satoh H, Hara M, Iso-o N, Togo $\mathrm{M}$, et al. Exclusive association of Paraoxonase-1with high-density lipoprotein particles in apolipoprotein A-I deficiency. Biochem Biophys Res Commun. 2001 Nov;289(2):395-401. DOI: 10.1006/bbrc.2001.5985

33. Codoner-Franch P, Navarro-Ruiz A, Fernandez-Ferri M, Arilla-Codoner A, Ballester-Asensio E, Valls-Belles V. A matter of fat: insulin resistance and oxidative stress. Pediatr Diabetes. 2012 Aug;13(5):392-9. DOI: 10.1111/j.1399-5448.2011.00847.x

34. Mackness MI, Durrington PN, Mackness B. How high-density lipoprotein protects against the effects of lipid peroxidation. Curr Opin Lipidol. 2000 Aug;11(4):383-8. DOI: 10.1097/00041433-20000800000007

35. Aviram M, Rosenblat M, Billecke S, Erogul J, Sorenson R, Bisgaier CL, et al. Human serum paraoxonase (PON 1) is inactivated by oxidized low density lipoprotein and preserved by antioxidants. Free Radic Biol Med. 1999 Apr;26(7-8):892-904. DOI: 10.1016/S08915849(98)00272-X

36. Demirel F, Bideci A, Cinaz P, Camurdan MO, Biberoğ- 
lu G, Yesilkaya E, et al. Serum leptin, oxidized low density lipoprotein and plasma asymmetric dimethylarginine levels and their relationship with dyslipidaemia in adolescent girls with polycystic ovary syndrome. Clin Endocrinol (Oxf). 2007 Jul;67(1):129-34. DOI: 10.1111/j.1365-2265.2007.02849.x

37. Kelishadi R, Cook SR, Amra B, Adibi A. Factors associated with insulin resistance and nonalcoholic fatty liver disease among youths. Atherosclerosis. 2009 Jun;204(2):538-43. DOI: 10.1016/j.atherosclerosis.2008.09.034

38. Kelly AS, Jacobs DR, Sinaiko AR, Moran A, Steffen LM, Steinberger J. Relation of Circulating Oxidized LDL to Obesity and Insulin Resistance in Chil- dren. Pediatr Diabetes. 2010 Dec;11(8):552-5. DOI: 10.1111/j.1399-5448.2009.00640.x

39. Johnston N, Jernberg T, Lagerqvist B, Siegbahn A, Wallentin L. Improved Identification of Patients with Coronary Artery Disease by the Use of New Lipid and Lipoprotein Biomarkers. Am J Cardio. 2006 Mar 1;97(5):640-45. DOI: 10.1016/j.amjcard.2005.09.123

40. Li R, Oteiza A, Sørensen KK, McCourt P, Olsen R, Smedsrød B, et al. Role of liver sinusoidal endothelial cells and stabilins in elimination of oxidized low-density lipoproteins. Am J Physiol Gastrointest. Liver Physiol. 2011 Jan;300(1):G71-81. DOI: 10.1152/ajpgi.00215.2010 
